\title{
Quality Improvement Model of History Education at University
}

\author{
Suwito Eko Pramono ${ }^{1 *}$, Heriyanto ${ }^{2}$, Inaya Sari Melati ${ }^{3}$ \\ ${ }^{1}$ Universitas Negeri Semarang, Sekaran Campus C7 Building FIS Gunungpati Semarang City, Indonesia \\ 2,3Universitas Negeri Semarang, Sekaran Campus L2 Building Economic Faculty Gunungpati Semarang City, Indonesia
}

\begin{abstract}
The implementation of history education at universities has not yet seen able to give optimal results. This study aims to propose a model for improving the quality of history education in higher education. It poses the primary research question: what is the quality improvement model of history education like according to the needs analysis? The research was conducted via a descriptive qualitative method. Data sources consisted of learning activities and documents related to the implementation of history education. Data analysis was carried out using interactive analysis models procedures. The results have revealed that history learning is currently only a transfer of information activity so that it cannot produce good-quality graduates who think deeply and critically. Methods that stimulate discussion of knowledge and hone critical thinking skills are not yet considered. Therefore, the quality of history education is relatively low and has no impact on improving the quality of graduates. The proposed model is relevant to be applied at universities, and has the characteristics of a problem-based learning approach and interactive discussion. If applied consistently, it has potential to promote critical thinking and problem-solving skills of students.
\end{abstract} Keywords: university level, quality improvement, history education, graduate quality

\section{INTRODUCTION}

History has so far been seen as an unimportant field of study (Printina, 2019; J. Sutimin \& Sariyatun, 2018). This view is based on several arguments such as history does not have a direct relationship with economic activity (Van Boxtel \& van Drie, 2017) and it does not assist the attitude and ability developments of students to enter post-school employment (Susilo, 2020). History is still considered a subject with insignificant impacts; no pragmatic values that students can use in society exist (Ahmad, 2016; Pinto \& Ibañez-Etxeberria, 2018). This implies that history is seen as a science that is not able to provide a meaningful perspective or provision for the development of post-school activities, especially those related to economic activities (Suryadi, 2012). Also, employment related to the historical discipline is very limited. It is reinforced by a very pragmatic pattern of community life, in which issues related to profit are materialistically becoming the basis and main orientation (Allman, 2019). History got impacted by such a mindset resulting in its obscure position among other disciplines.

If analyzed carefully, the preceding problem is a weakness in the actualization of history learning is carried out as the implementation of history education (Havekes et al., 2010). It can be identified based on the approach, material, and teaching model used in the classroom (Endacott \& Brooks, 2018). Various facts show that lectures at universities are only a knowledge transfer process (L. A. Sutimin, 2019). This process is not entirely wrong if related to the fact that historical events need to be discussed and studied systematically. That is, mastery of knowledge concepts is an important provision or foundation in studying and analyzing historical events
(Wineburg, 2018). Thus, knowledge transfer is a notable part of the course. Besides, studying and analyzing these events require mastery of broad scientific concepts as an approach (Bourdillon, 2013). Sciences to complement students' historical understanding are economics, sociology, anthropology, politics, geography, and even ethics. Concepts in these disciplines can be the basis for creating a comprehensive and critical discussion of knowledge. Unfortunately, this cannot be found in the historical education system currently implemented in Indonesia.

Previous studies related to the quality of history education are found such as in a study conducted by (Firdaus et al., 2021), denoting that the current education quality cannot rely on a one-way learning pattern; it is necessary to pay attention to the methods and approaches students' need to be active in the classroom. (Amboro, 2020) then

Corresponding Author e-mail: suwitoekop@mail.unnes.ac.id https://orcid.org/0000-0002-6486-5260

How to cite this article: Pramono SE, Heriyanto, Melati IS, (2021). Quality Improvement Model of History Education at University. Pegem Journal of Education and Instruction, Vol. 11, No. 4, 2021, 320-328

Source of support: This research was funded by Lembaga Penelitian dan Pengabdian Kepada Masyarakat Universitas Negeri Semarang Tahun in 2020

Conflict of interest: None.

DOI: 10.47750/pegegog.11.04.31

Received: 07.06.2021

Accepted: 20.08.2021 Publication: 01.10.2021 
explains in his research that history education these days needs to adopt techniques, methods, media, and various learning resources developed by educators by adjusting the conditions of students. It can spur practical and contextual understanding of history through a process of discussion and opinion exchange in class - even by debating. In essence, history education will establish an understanding that is not only textual and rote, but also forms a critical and conscious public mindset. (Suparjan, 2019) recommends creating a more actual historical education quality improvement model by adjusting the current needs of students. Thus, various lecture activities can have a significant impact on the development of historical knowledge and contextual ways of thinking. Its development can be done by incorporating elements of the latest methods, media, and learning resources to attract active students.

Based on the preceding reviews, there are indications that the current model of history education at universities is still not quality-oriented. The lecture process tends not to meet expectations and therefore implies unqualified graduates of history education programs (prospective history teachers) (Labaree, 2018; Susilo, 2020). This means that the preparation of qualified history teacher candidates must begin by improving the lecture process by prioritizing quality in each of the lecture activities (Clark, 2011). Thus, improving the quality of lectures is also the most effective strategy to produce better graduates (prospective history teachers).

Departing from this condition, this study aims to develop the quality improvement model of history education that is appropriate to be applied in universities. This research is expected to contribute to improving the quality of the historical education process that prioritizes critical thinking activities, knowledge discussions, and democratic processes in history classes. It is hoped that with the proposed model, the quality of history education program graduates expected to be history teachers in secondary schools would be better. The question answered in this research is: what is the appropriate model for improving the quality of history education for higher education?

Quality improvement in lectures is a rational and realistic thought to upgrade the quality of history education. It should be implemented based on various theoretical frameworks as follows. First, history is essentially an unending dialogue between the present and the past (Carr, 2018). It is not just a story coming about in the past that is arranged systematically and objectively based on the scientific method; it also speaks for meanings for the benefit of the present (Absor, 2020). Therefore, history learning does not only study the facts of past events, but also contains studies and analyses of the relationship between the past and the present-as well as an effort to find the meaning of past events. This situation allows history to provide perspectives and contributions in studying and analyzing the problems of life in terms of state, nation, and society.

Second, history as fact, story, and science has educational, inspirational, recreational, and justification functions (Arthur, 2012). The educational function can be obtained either from the positive and negative values contained in every historical event. The history of civilization and culture contains a high educative function as it can be utilized as the basis for developing greater attitudes and behavior (Ahyani, 2014). Inspirational function, as another aspect, speaks about history as a source of inspiration for one to do or not to do certain actions (Cooper, 2016). One's creativity cannot be separated from past experiences or certain history.

The recreational function then can be acquired by reading stories about historical events. This activity in fact does not only increase knowledge, but also becomes a medium of recreation by following and remembering historical events with various aspects and implications (Pramono et al., 2019). Meanwhile, the justification function can be achieved by utilizing history as a tool to justify an action. This function must be applied carefully as history is often used as a justification or condonation. The Order of Eleventh March (Super Semar) in 1966 is one of the greatest examples (Adam, 2018). These functions cannot be actualized if history learning is not accompanied by critical study and analysis.

Third, history is a very comprehensive field of study as every single historical event must be studied and analyzed in-depth based on the perspective of other sciences (Husni, 2020). Anthropology, for instance, is an auxiliary science in studying and analyzing the history of culture. In fact, the process of assimilation, acculturation, and enculturation cannot be understood in depth if it is not analyzed with anthropology. The study and analysis of social-historical events based on a sociological perspective can provide broad and complete knowledge and insight about people's lives, including their classification and social institutions (Ainina, 2014). The meaning of historical events can be acquired through systematic study and analysis based on political, economic, geographic, and even ethical perspectives.

History, in addition to containing knowledge, possesses values that are very important as a basis in shaping the attitudes and personality of students (the next generation of the nation) (Rajilun, 2019). Therefore, its learning as the implementation of history education must be execited in a planned and directed manner through strategies, approaches, and methods that prioritize critical analysis. Hence, students can understand the nature of history and find the meaning of every past event for the benefit of living in the present and future optimally.

Fourth, history can be a source of best practice thinking, as well as future practice (Ashby, 2010). With its advantages and disadvantages, history can be the basis for developing attitudes and behavior patterns in terms of state, nation, and 
society lives. This kind of thinking is called best practice, where historical events can be branding in developing a better life (Amboro, 2019). Basically, the concept of best practice is in line with the educational function of history (Ahmad, 2012). However, it has a weakness as individuals tend to be reluctant to get out of their comfort zone. Therefore, future practice must be the orientation of history learning so that each student can determine what to do in the present or future. In essence, future practice is under the inspirational function of history.

Fifth, history cannot be utilized as a tool or basis for predicting events that are going to happen (Suharso, 2017). Various explanations about the role and function of history cannot be seen as justification in determining history as a predictor. Historians who want to predict future events based on past ones should stop being historians (Lee, 2017). For example: a democratic and wise king will always get the support of the people in running the government. This fact cannot be used as a tool to predict that a democratic and wise head of government will be loved by his people. Therefore, critical study and analysis is an important part in studying every historical event with its advantages and disadvantages.

In modern and pragmatic society, the role and function of history are seen as irrelevant since past events only happened once so they cannot be utilized as parameters. Nonetheless, Wineburg (2018) says that in the modern era, the function of history education will not lose anything from its importance. Without knowing the history completely and correctly, one cannot get a qualitative understanding of various social phenomena. In fact, not a few community groups have lost their identity and cannot continue a real-life as they forget their past experiences (Wibowo, 2014). The success of Japan's modernization is because they are always put steps based on the history and culture of their nation. Thus, history learning has a strategic role and function in achieving the goal of developing quality human resources.

Based on the preceding concept, as the implementation of history education, the history lecture process must be held in a planned, directed, and sustainable manner based on the nature of history and by using strategies or approaches that allow optimal implementation of critical analysis. In other words, learning history is not only a knowledge transfer, but also a transfer of values (Wineburg, 2010a). That way, history lectures can make a significant contribution in preparing noble and competent graduates.

The actualization of history education can be manifested optimally if only the graduates meet the following criteria.

- Competent in understanding the nature of history as fact, story, and science, as well as the function of history in human life, society, nation, and state. This ability acts as an important capital or provision in developing appropriate, effective, contextual, and meaningful history learning materials.
- Competent in understanding the philosophical foundation of history education. This ability is very notable as it can help history educators in formulating the goals and meaning of history based on rational and objective thinking or approaches.

- Competent in understanding auxiliary science concepts such as sociology, politics, economics, anthropology, geography, and culture. It is very primary because it can assist history educators in analyzing various past events comprehensively. For that, every history educator must understand thoroughly the body of knowledge in studying historical events.

- Competent in understanding the nature (science) of education, especially those related to pedagogical principles. Pedagogical competence is very helpful for history educators in managing fun, effective, efficient, contextual, and meaningful learning. This means that every history educator must have the ability and skills to apply learning strategies and methods and carry out assessments of learning outcomes (Pramono, 2014).

- Competent in understanding the nature of history education. Every history educator must understand the function and meaning of history that can help them in determining learning objectives under the nature and principles of history education

\section{Method}

This study was generated based on the results of a research on the antecedents of lecturers' academic performance (Pramono, 2019). It was conducted at four universities possessing performance basis as Training Institution for Educational Personnel (LPTK), namely universities assigned by the Government to organize teacher procurement programs in early childhood education through formal education, basic education, and/or secondary education, and to organize and develop educational and non-educational sciences. The research took locations at Universitas Negeri Semarang, Universitas Negeri Medan, Universitas Negeri Surabaya, and Universitas Negeri Manado.

This research was carried out by applying descriptive qualitative methods (Creswell \& Creswell, 2017). The data sources were learning activities and documents related to the implementation of history learning at universities. Data collection was executed by means of observation and document study. The analysis was carried out with consecutive (successive) procedures from the observation to learning activities. The researcher then analyzed documents related to the implementation of history education. The validity of the collected data was then tested utilizing source triangulation techniques and method triangulation. The triangulation was applied by exploring the truth of information based on data obtained by various methods and sources. For example, besides 
ensuring that observational data was already suitable with the need, the researcher also examined data from document studies related to the implementation of history learning at universities. Data with the same category would be compared, concerning whether the information was mutually reinforcing or contradictory, so that data produced in that process could meet the conditions for analysis.

Data analysis was held using interactive analysis models (Miles et al., 2014). In this research, the analysis process was done through four stages. The first was data collection. The data obtained from the results of observations and document studies were recorded in field notes consisting of two parts, namely descriptive and reflective parts. Descriptive notes are described as a record of what is witnessed, heard, seen, and experienced by the researcher without any interpretation and opinion on the phenomena he experiences. Reflective notes, on the opposite, are notes that contain the impressions, opinions, comments, and interpretations of researchers regarding the findings. Moreover, this kind of note is material for data collection plans for the next stage. The second stage in the analysis was data reduction. After the data had been collected, data reduction was made to determine relevant and meaningful data, as well as focusing on the data that could lead to problem-solving, discovery, meaning, or to answer research questions. Next, the researcher systematically simplified, compiled, and described important things about the findings and their meanings. In the data reduction process, only data findings or findings related to research problems were reduced. Meanwhile, the unrelated data was discarded. In other words, data reduction was used for analysis that directed, categorized, sharpened, and discarded unimportant stuff and organized data. This facilitated the researcher to draw conclusions.

The third stage was data presentation done descriptively and analytically. The purpose of data presentation was to combine information so that it could provide an overview of the actual situation. In this case, it was helpful so that researcher did not experience difficulties in mastering information properly and thoroughly. Therefore, the researcher made a description regarding the proposed model that was being developed to facilitate the mastery of the data or information. In this way, the researcher controlled the data and did not sink to hasty conclusions. Only qualified and categorized data would be analyzed. The main category of data was the quality of history education which was analyzed based on learning activities and documents related to the implementation of history education at universities.

The last stage is conclusion drawing. This phase was done during the study. Alike the data reduction process, after the data had been collected and judged adequate, temporary conclusions were obtained. Final conclusions were drawn up after the data were completed.

\section{Results and Discussion Essence of Quality History Education}

History education is a conscious and planned effort to create an atmosphere of learning that allows students to develop their potential so that they have attitudes, abilities, and skills by utilizing various media and methods (Öztürk, 2011). For this reason, every history educator must understand and think critically about the position of history. At least, three historical positions have been generally recognized, namely: a) history as fact; b) history as story; and c) history as science of past events (Wineburg, 2010b). History as fact or story has an important position and meaning, especially in its development as a science (Rahman, 2017). Hence, historical facts and stories of the past must be analyzed so that the truth can be justified scientifically.

Historical facts are methodologically evidence of past events that are recognized as true as they have been tested through internal and external criticism. That is, the objectivity of historical facts does not need to be debated anymore. Historical facts are a source of historical writing which is basically a very important science (Carr, 2018). Without the support of valid historical facts, the writing of history cannot be carried out accurately and objectively. However, historical writing is not free from subjectivity as it must be written based on the results of interpretation, yet historians try to write history objectively. In fact, they can produce critical history thanks to their ability to utilize the social sciences as the basis for their interpretation (Sulaiman, 2012). The toughest challenge in writing critical and objective history is when there is intervention from the government requiring the justification function of history.

History as story about past events is often seen as not featuring scientific standards because it tends to be subjective (Ahmad et al., 2014). The story told by a historical actor tends to be excessive (subjective) as it does not match reality. For example, a historical actor during the war of independence claimed to have played a big role because he was always at the forefront of the battlefield, even though he only played a role in the soup kitchen. Nevertheless, this history function is still important since it can be an initial provision for writing history as science-although it must be accompanied by hard work to get objective truth. History as story is increasingly important when it is associated with the lives of traditional people who have not left written traces.

Various facts of the past sometimes cannot provide complete information and therefore must be supplemented with stories so that the next generation has a proper understanding of them. However, history as story is not always accompanied by concrete facts. This fact cannot be separated from the historical development itself (Alfian, 2011). Broadly speaking, historical development started from a tradition called the little tradition which gave birth to oral history, and the great tradition which 
gave birth to written history (Carr, 2018). The little tradition developed among the cloud community who are unable to read and write so that storytelling traditions were established from generation to generation. Meanwhile, the great tradition was developed in the palace under the leadership of the king who was accompanied by poets. Usually, poets could read and write so that a written tradition was increasingly shaped.

History as fact and history as story is viewed as unimportant as they are not accompanied by the essential meaning of the fact or story. This fact can be understood because of the limited ability to find the meaning of a fact or a past story (Suryadi, 2012). This is quite ironic since every fact or story of the past has a high meaning for human life. For example, stories about Rawa Pening (in Central Java) or Malin Kundang (in West Sumatra) are very meaningful for people's lives nowadays as both contain high philosophical values. Thus, it is not an exaggeration if history has meaning or significance for human life in the present and future.

The preceding thinking can be proven through the efforts of society or humans in improving, achieving progress, or solving life problems; people tend to use their experiences as considerations in doing things (Amboro, 2020). Success, advantages, failures, and shortcomings in the past can commonly assist the community in escalating or solving the problems it faces. In modern society, this thinking is in line with the view of the philosophical school of empiricism, where in achieving progress, one must not forget the past. The term best practices or the experience is the best teacher is often used in the world of education (Pramono, 2014). Thus, past events have meaning or significance in building a better present and future life.

The importance of history becomes crystal clear at the time it is placed as a science, where it is compiled in certain ways that can be scientifically justified based on different theories and methods from other sciences (Prayogi, 2021). Therefore, history learning must be carried out based on educational concepts. This process must be improved from a model of memorizing facts to a model of critical thinking. That way, the students are able to understand the meaning and value of each event. This thinking is in accordance with Carr (2018)'s view, stating that "not knowing history can be likened to people reading a romance book only the last page because not knowing the "intrigue of the story" and its "happy ending" cannot be understood in-depth". The meaning of history for the benefit of human life can be traced from the statement: "Knowing yourself means knowing what you can do and since nobody knows what he can do until he tries, the only clue to what man can do is what man has done. The value of history, then, is that it teaches us what man has done and thus what man is" (Collingwood, 1994).

The ideas above can be implemented easily in learning as history lecturers have understood the role and function of history as an educational medium, especially as character education. In fact, historical concepts can even guide someone or become a basis for thinking systematically and analytically about a problem of society, nation, and state. This is because no problem is free from place and time. That is, every problem must be seen as a continuity from the past and historical thinking can help in solving that problem (Ahyani, 2014). Thus, history learning must be able to provide students with provisions to think systematically and analytically, understand the importance of working in a team, solve problems, have good communication skills, be persistent, and empathize.

Students must be able to interpret historical facts from various scientific perspectives (Arthur, 2012; Cooper, 2016). Thus, placing history as science is the obligation and responsibility of history lecturers so that learning becomes a meaningful process of transforming critical information. This is the essence of historical education which must always be the basis, as well as the orientation of history learning. This idea must be greatly implemented in real terms by using the right learning approach. That is, a learning approach that is under the characteristics of the material being studied tends to be more successful and efficient than simply wanting to apply a new learning approach. Moreover, the application of the learning approach must be adapted to the potential of students and the ability of history educators.

\section{Approach of Quality History Learning}

The selection and application of the learning approach is a determinant of the success of history learning (Putro, 2012). Moreover, if learning is seen as the implementation of history education. Therefore, every educator must be able to choose the most effective and efficient learning approach. This selection must be based on various considerations, including: a) the characteristics and aspects of the learning material being studied; b) learning objectives to be achieved; c) the ability of educators to apply a learning approach; d) the potential and readiness of students; e) availability of learning resources; and f) the availability of media and learning infrastructure. Various learning approaches that are considered the most sophisticated and referred to as scientific approaches such as problem-based learning, project-based learning, discovery learning, inquiry learning will be meaningless if history educators do not understand the nature and meaning of history education. This thinking is in line with the learning principles recommended in the 2013 Curriculum, which are fun, contextual, effective, efficient, and meaningful. Thus, history learning is not just a transfer of knowledge process, but must be a transfer of values. In short, history learning must be placed as an effort to find the value of each past event and that value is the basis for determining meaning for the present and future interests.

To achieve the goals and functions of history education, every history educator must be equipped with adequate 
capabilities. The capabilities referred to include: a) understanding the position of history as fact, as story, as well as science; b) understand the function of history education from a philosophical perspective; c) understand social science concepts to support critical analysis; d) skillful in implementing history learning methods and approaches effectively and efficiently; and e) skilled in assessing history learning outcomes, both in the cognitive aspect and in the affective aspect. Thus, history learning as the implementation of history education can be actualized optimally.

\section{Definition, Position, and Function of Historical Knowledge for Quality Improvement}

History is the study of past events and phenomena systematically, objectively, and chronologically (Clark, 2011; Lee, 2017). Systematic means that the study is carried out based on the methods and principles of History as a science for it has a unique method or way of working than that of other sciences. The historical method consists of heuristics, internal and external criticism, interpretation, and historiography (Zed, 2018). Heuristics is the process of historical tracing. Heuristics allow historians to obtain sufficient data and information about past events.

Internal and external criticism enables historians to produce historical facts that are relevant, valid and following the needs of historical writing. The criticism is a very important step in the work of historians since the writing of objective history cannot be guaranteed solely from large amounts of data and information. Therefore, it must be carried out in the right way with the right technique and can be justified methodologically. However, the collection of historical facts obtained only serves as a basis for objective historical writing and cannot be used as a basis for critical historical writing.

Based on the facts above, the interpretation of historical facts becomes a very important and most difficult part. In addition to being carried out based on relevant supporting scientific concepts, historical interpretation must be carried out objectively (Carr, 2018). It means that subjectivity, as part of the mindset, perspective, attitude, and behavior of historians, is an obstacle to the implementation of an objective interpretation. Therefore, historians must be able to explain historical facts in a precise, straightforward, logical, and objective manner based on the results of the interpretation of historical facts. Further, the interpretation must serve as a help for observers and readers of history in understanding and finding the meaning of each historical event. Historiography allows historians to write history correctly and following the principles of scientific writing.

When associated with a progressive philosophy, education aims to achieve the highest progress in the future. Hence, the implementation of education must be oriented towards the future and disoriented from the past. Thus, looking back to the past (history education) is deemed as something that is not important as it does not influence the progress that is aspired to. However, the views of the followers of this progressive philosophy are opposed by the followers of the philosophical school of empiricism who view that to achieve progress in the future, one must not forget what has been done in the past (Lee, 2017). The past is a mirror, as well as a window to see the various advantages and disadvantages of human activity. Thus, learning from the past (history education) is a necessity in achieving better goals or ideals.

Based on the explanation above, historical education has a strategic role and function in building the future, including the development of human resources.

\section{Role and Function of History}

The views of the followers of progressive philosophy cannot be accepted as truth because in building the present and future life it is impossible to forget what has happened in the past. This group then developed a philosophical school of empiricism (Vygotsky, 2012). Fun learning can be done in various ways to make it suitable and comfortable for the students so that they can focus and relax in following the lesson. After greeting, start the lesson with a simple question. For example, who has read the newspaper this morning? Is there any interesting news? These kinds of questions can be used as a trigger for the students to be more active in a discussion and make them get used to active learning. In addition, by doing magic opening in learning, students will be challenged to be enthusiastic and responsive to every instruction given by the teacher, so that the learning process can go interactively.

\section{Proposed Quality Improvement Model of History Education in Higher Education}

This article is derived from the results of research that examines and analyzes the performance of lecturers in implementing the three pillars (Tri Dharma) of higher education. This study succeeded in producing 2 (two) models to improve the quality of history education, namely the factual model (existing) and the alternative model (proposed). The factual model describes the history lecture process that has been carried out so far. While the alternative model is the result of development to improve the quality of history education.

Basically, the history lecture process that has been carried out in the history education study program has been relatively constructive, rational, and realistic. Lectures are carried out based on the curriculum of the study program, especially those related to course descriptions, course content, and course objectives. Thus, every lecturer has understood the scope, content, and objectives of the lecture. In general, history lectures are always oriented towards facts, events or occurrences, and cause and effect. Therefore, lectures tend to 
be a transfer of knowledge (Pramono, 2014) and less emphasis on critical analysis so that the actualization of transfer of values cannot be carried out optimally (Clothey, 2016).

The application of strategies and lecture methods is a major weakness since it is less oriented to student activities. In addition, the nature of history education has not been optimally elaborated in lectures so that students are not able to understand the meaning of each historical event. For example, in the understanding of the events of the Boston Tea Party, it is only interpreted as the disposal of tea originating from India into the sea in the port of Boston. In fact, the event could not be separated from the policy of the British colonial government which was seen as detrimental to the American people in general, the tea farmers in particular. Therefore, every government policy must be considered rationally and objectively for it not to harm certain parties. This is the meaning of the Boston Tea Party event that students must understand.

Another example is the foreign policy of Cavour (Prime Minister of Piedmont-Sardinia) in the mid-19th century. At that time, Italy was in a state of fragmentation into 10 small countries and most of them were under the influence of Austrian rule. In realizing the unification of Italy, Cavour defended and helped France to oppose the Russian Warm Water Policy. Physically, Cavour's attitude is in stark contrast to the state of Piedmont-Sardinia which is still very weak. Why did Cavour carry out a foreign policy that was not compatible with his domestic situation? This foreign policy made a real contribution to the achievement of Italian unification. This fact must be analyzed critically so that students can understand historical facts and the true meaning of each historical event.

Cavour's foreign policy is very effective and efficient because it produces very valuable commitments. Cavour did not expect a military or economic response from France, but only hoped for a neutral French attitude in the event of a war

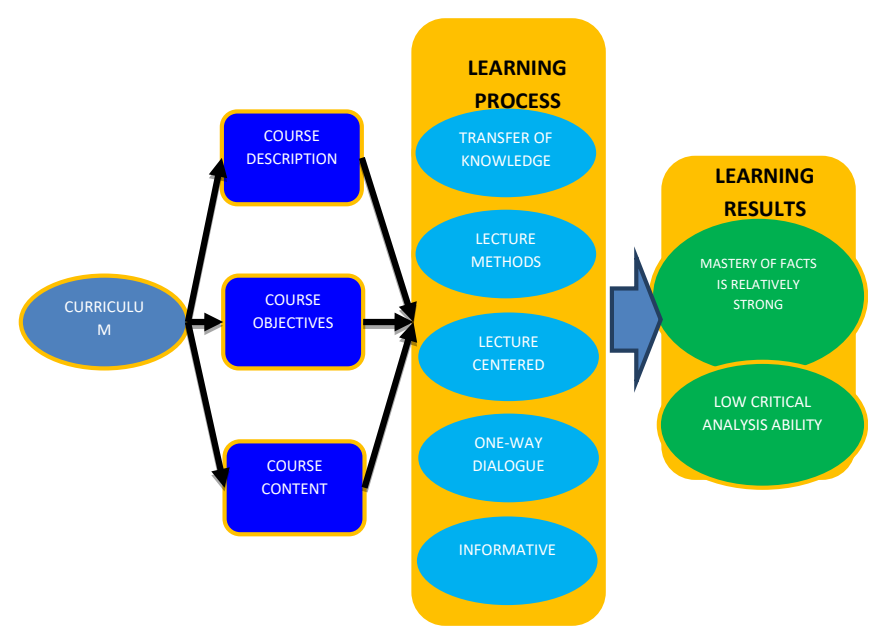

Figure 1: Factual Model of History Education (Existing Model) between Austria and the Italian Confederation under the leadership of King Victor Emmanuel I of Piedmont-Sardinia. In fact, Cavour is willing to give up Monaca and Nice to compensate for France's neutral stance. Thus, the struggle for Italian unification was relatively expensive and relied only on its own strength. In short, ordinary people cannot always fully understand government policies. This is the meaning of every policy that must be analyzed systematically, systemically, and objectively.

Historical events not only illustrate facts and cause-andeffect relationships (Carr, 2018; Cooper, 2016; Wineburg, 2010a), Was the ocean voyages that Europeans carried out in the 17th century the result of the Crusades, technological advances and developments, the fulfillment of industrial basic materials, the expansion of the market for industrial products, or fulfilling the needs of spices? This issue must be analyzed critically because every historical event in one place has a relationship with historical events elsewhere (J. Sutimin \& Sariyatun, 2018), even though it is indirect. Therefore, history lectures are not just a transfer of knowledge, but a transfer of values so that the meaning of historical events can be optimally understood and used as a basis for developing people's behavior in the present and the future.

Based on the facts above, history lectures must be improved so that history education can be actualized optimally. In other words, the quality of history lectures must be improved so that students can understand the facts and meaning of each historical event logically and realistically. For this reason, the quality improvement model of history education offered through this paper is expected to be an alternative solution in improving history lectures. The proposed quality improvement model of history education is presented in Figure 2.

Conceptually, the principles of lectures based on the curriculum, description, content, and objectives of the history course are still being implemented. Meanwhile, the basic

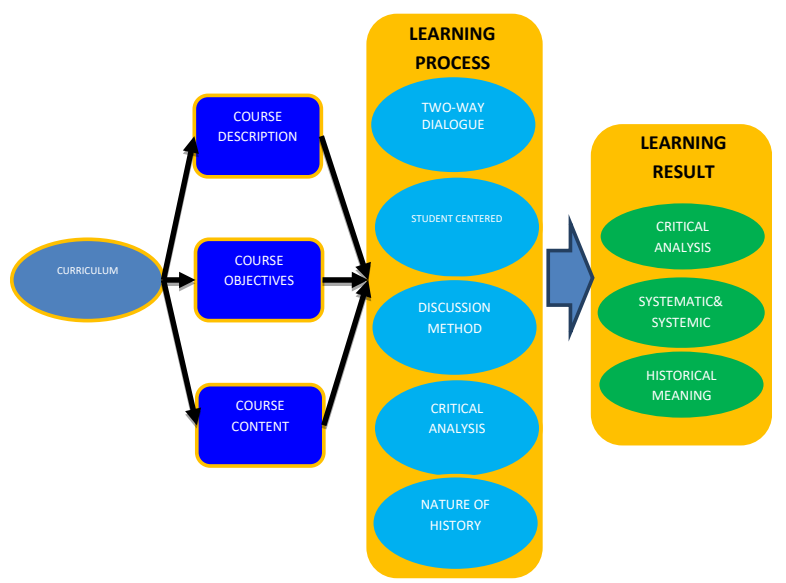

Figure 2: Quality improvement model of history education (Proposed Model) 
change in the quality improvement model of history education is focused on improving the history lecture process. At least, there are 5 (five) principles that must be applied in history lectures, namely: a) the nature of history as an orientation to learning history; b) student-centered learning strategies; c) interaction between students and learning resources; d) two-way dialogue as knowledge sharing; and e) critical analysis.

The nature of history must be the main foundation in history lectures so that students can understand the meaning of each historical event for their present and future interests. For this reason, the right lecturing strategy and method is a wise choice because it allows students to play an active role in lectures (Bourdillon, 2013). For example, problem-based learning, discussion, recitation are strategies and methods that deserve to be the main choice. Thus, the interaction between students and learning resources can be realized optimally and intensively.

Another very important issue is dialogue between students and lecturers or between students and students so that knowledge sharing occurs. This dialogue process is even more important if it is based on critical thinking or analysis (Ahmad et al., 2014; Sardabi et al., 2018). Thus, every historical event can be studied in-depth and comprehensively because critical analysis must be carried out based on broad and diverse perspectives. This analysis becomes more important because historical events are related to various aspects of life, whether political, economic, social, cultural, as well as the values of life that are upheld by civilized society.

When associated with theory and empirical data, the proposed quality improvement model of history education is rational and realistic thought. Therefore, history lectures must be based on principles that are considered right and good, and are oriented towards essential goals and results, namely graduates who are competent, creative, innovative, and adaptive. Competent means mastering scientific concepts (facts and causal relationships) (Sulaiman, 2012). Creative, innovative, and adaptive are the abilities to use historical facts as the basis for developing a better way of thinking by prioritizing rationality to face and solve every problem that has been familiarized with problem-based learning activities. In the end, the proposed quality improvement model of history education will be relevant and applicable in history education programs in universities to improve the quality of learning which implies the improvement of the quality of graduates.

\section{Conclusion}

History education conducted in universities still follows the old style; one-way learning, high dependence on teachers, students who are accustomed to not being independent, and the process of discussing knowledge with a critical approach that tends to be avoided. After the world changed and the democratization of education began to spread to every aspect of the education system in various countries with one of them was Indonesia, history education started to receive a lot of criticism. It was stated that the knowledge transfer process could not be carried out in a one-way way, which so far had produced graduates who have low quality. For this reason, a quality improvement model of history education that is based on knowledge discussion activities, emphasizes critical understanding, and is oriented towards standard quality education is needed. The urge to create the model is getting stronger after analysis of learning at several universities shows results that were not as expected. Finally, the said model has been developed. It opens up opportunities for the formation of competent graduates, has strong historical knowledge, and have critical thinking skills by understanding the context of the situation so that graduates of the history education program will be better. There is a quality process that can be relied on to create quality educational outcomes that are useful for improving the current state of history education. This research implies that the developed quality improvement model of history education needs to be applied in universities to see the extent of its impact on improving the learning quality, as well as the extent to which the model can be effective and efficient in creating graduates who can think critically and adaptively and mastering problem-solving skills by prioritizing knowledge discussion.

\section{References}

Absor, N. F. (2020). Pembelajaran Sejarah Abad 21: Tantangan dan Peluang dalam Menghadapi Pandemi Covid-19. CHRONOLOGIA, 2(1), 30-35.

Adam, A. W. (2018). Beberapa catatan tentang historiografi Gerakan 30 September 1965. Archipel. Études Interdisciplinaires Sur Le Monde Insulindien, 95, 11-30.

Ahmad, T. A. (2012). Pembelajaran Sejarah Dalam PerspektifCritical Pedagogy. Semarang: Historia Pedagogia.

Ahmad, T. A. (2016). Sejarah Kontroversial Di Indonesia: Perspektif Pendidikan. Yayasan Pustaka Obor Indonesia.

Ahmad, T. A., Sodiq, I., \& Suryadi, A. (2014). Kendala-Kendala Guru dalam Pembelajaran Sejarah Kontroversial di SMA Negeri Kota Semarang. Paramita: Historical Studies Journal, 24(2).

Ahyani, N. (2014). Kemampuan Berfikir Kritis Dalam Pembelajaran Sejarah. Prosiding Seminar Nasional Teknologi Pendidikan.

Ainina, I. A. (2014). Pemanfaatan media audio visual sebagai sumber pembelajaran sejarah. Indonesian Journal of History Education, 3(1).

Alfian, M. (2011). Pendidikan Sejarah dan Permasalahan yang dihadapi. Khazanah Pendidikan, 3(2).

Allman, P. (2019). Critical education against global capitalism: Karl Marx and revolutionary critical education. Brill Sense.

Amboro, K. (2019). Kontekstualisasi Pandemi Covid-19 dalam Pembelajaran Sejarah. Yupa: Historical Studies Journal, 3(2), 90-106.

Amboro, K. (2020). Sejarah Publik dan Pendidikan Sejarah Bagi Masyarakat. Historis: Jurnal Kajian, Penelitian Dan Pengembangan Pendidikan Sejarah, 5(1), 20-28. 
Arthur, J. (2012). Issues in history teaching. Routledge.

Ashby, R. (2010). Understanding historical evidence: Teaching and learning challenges. In Debates in history teaching (pp. 151-161). Routledge.

Bourdillon, H. (2013). Teaching history. Routledge.

Carr, E. H. (2018). What is history? Penguin UK.

Clark, P. (2011). New possibilities for the past: Shaping history education in Canada. UBC Press.

Clothey, R.A. (2016). Increasing diversity in in international education:programming for non-traditional students through an alternative model. International Journal of Curriculum and Instruction, 8(1), 22-35.

Collingwood, R. G. (1994). The idea of history. Oxford University Press on Demand.

Cooper, H. (2016). Teaching history creatively. Taylor \& Francis.

Creswell, J. W., \& Creswell, J. D. (2017). Research design: Qualitative, quantitative, and mixed methods approaches. Sage publications.

Endacott, J. L., \& Brooks, S. (2018). Historical empathy: Perspectives and responding to the past. The Wiley International Handbook of History Teaching and Learning, 203.

Firdaus, E., Purba, R. A., Kato, I., Purba, S., Aswan, N., Karwanto, K., \& Chamidah, D. (2021). Manajemen Mutu Pendidikan. Yayasan Kita Menulis.

Havekes, H., Aardema, A., \& De Vries, J. (2010). Active Historical Thinking: Designing learning activities to stimulate domainspecific thinking. Teaching History, 139, 52.

Husni, H. (2020). Character education in Indonesia: A historical outlook. Educational Review: International Journal, 17(1), 147-162.

Labaree, D. (2018). An Uneasy Relationship: The History of Teacher Education in the University 1. In Who Decides Who Becomes a Teacher? (pp. 68-88). Routledge.

Lee, P. (2017). History education and historical literacy. In Debates in History Teaching, Second Edition (pp. 55-65). Routledge.

Miles, M. B., Huberman, A. M., \& Saldana, J. (2014). Qualitative data analysis: A methods sourcebook. Sage Publications, Inc.

Öztürk, İ. H. (2011). Problem of anachronism in history teaching: An analysis of fictional texts in social studies and history textbooks. Journal of Social Studies Education Research, 2(1), 37-58.

Pinto, H., \& Ibañez-Etxeberria, A. (2018). Constructing historical thinking and inclusive identities: Analysis of heritage education activities. History Education Research Journal, 15(2), 342-354.

Pramono, S. E. (2014). Kinerja Guru Sejarah: Studi Kausal Pada Guru-Guru Sejarah SMA di Kota Semarang. Paramita: Historical Studies Journal, 24(1).

Pramono, S. E. (2019). Anteseden Kinerja Akademik Dosen. Lembaga Penelitian dan Pengabdian Kepada Masyarakat Universitas Negeri Semarang.

Pramono, S. E., Ahmad, T. A., \& Wijayati, P. A. (2019). The National Heroes in History Class. KnE Social Sciences, 119-129.

Prayogi, A. (2021). Paradigma Positivisme dan Idealisme dalam Ilmu Sejarah: Tinjauan Reflektif Terhadap Posisi Sejarah Sebagai Ilmu. Tamaddun: Jurnal Kebudayaan Dan Sastra Islam, 21(1), 75-90.
Printina, B. I. (2019). Pemanfaatan Media Komik Digital Melalui Unsur PPR (Paradigma Pedagogi Reflektif) Pada Matakuliah Sejarah Asia Barat Modern. Jurnal Pendidikan Sejarah, 8(1), $1-13$.

Putro, H. P. N. (2012). Model Pembelajaran Sejarah Untuk Meningkatkan Kesadaran Sejarah Melalui pendekatan Inkuiri. Paramita: Historical Studies Journal, 22(2).

Rahman, F. (2017). Menimbang Sejarah Sebagai Landasan Kajian Ilmiah; Sebuah Wacana Pemikiran Dalam Metode Ilmiah. EL-BANAT: Jurnal Pemikiran Dan Pendidikan Islam, 7(1), $128-150$.

Rajilun, M. (2019). The Use of Local Character's Biography to Build Nationalism and Patriotism. International Journal Pedagogy of Social Studies, 4(1), 41-50.

Sardabi, N., Biria, R., \& Golestan, A. A. (2018). Reshaping Teacher Professional Identity through Critical Pedagogy-Informed Teacher Education. International Journal of Instruction, 11(3), 617-634.

Suharso, S. (2017). Pembelajaran Sejarah Lokal Pada Kelas Sejarah (Model Pengembangan Bahan Ajar Sejarah Lokal Kota Kudus Dalam Rangka Meningkatkan Minat Siswa Pada Sejarah). Jurnal Sejarah Dan Budaya, 11(1), 95-111.

Sulaiman, S. (2012). Pendekatan konsep dalam pembelajaran sejarah. Jurnal Sejarah Lontar, 9(1), 9-21.

Suparjan, E. (2019). Pendidikan Sejarah Untuk Membentuk Karakter Bangsa. Deepublish.

Suryadi, A. (2012). Pembelajaran Sejarah dan Problematikanya. Jurnal Historia Pedagogia, 1(1), 74-84.

Susilo, A. A. (2020). Peran Guru Sejarah Dalam Pemanfaatan Inovasi Media Pembelajaran. Jurnal Komunikasi Pendidikan, 4(2), 79-93.

Sutimin, J., \& Sariyatun, A. (2018). The Development of Deconstructive of Learning History Model to Promote The Higher Order Thinking Skill of University Students. The New Educational Review, 51(1), 19-29.

Sutimin, L. A. (2019). Development of Students' Knowledge of History: Acceptance and Rejection of the Indonesia-Malaysia Confrontation Narratives. Journal of Social Studies Education Research, 10(2), 290-307.

Van Boxtel, C., \& van Drie, J. (2017). Engaging students in historical reasoning: The need for dialogic history education. In Palgrave handbook of research in historical culture and education (pp. 573-589). Springer.

Vygotsky, L. S. (2012). The collected works of LS Vygotsky: Scientific legacy. Springer Science \& Business Media.

Wibowo, H. S. (2014). Efektivitas Pembelajaran Sejarah dengan Mengunakan Model Pembelajaran E-Learning. Indonesian Journal of History Education, 3(1).

Wineburg, S. (2010a). Historical thinking and other unnatural acts. Phi Delta Kappan, 92(4), 81-94.

Wineburg, S. (2010b). Thinking like a historian. Teaching with Primary Sources Quarterly, 3(1), 2-4.

Wineburg, S. (2018). Why learn history (When it's already on your phone). University of Chicago Press.

Zed, M. (2018). Tentang konsep berfikir sejarah. Lensa Budaya: Jurnal Ilmiah Ilmu-Ilmu Budaya, 13(1). 